\title{
UTILIZING HOUSE YARDS TO GROW PRODUCTIVE CROPS AT PELAMBUAN SUB-DISTRICT, BANJARMASIN MUNICIPALITY
}

\author{
Andi Suci ANITA, Edward ZUBIR, Mukhyar AMANI \\ Jurusan Biologi, FMIPA Universitas Terbuka \\ Email: andisuci@ecampus.ut.ac.id
}

\begin{abstract}
Improving people's welfare is the main goal of development, which can be achieved among others through the intensive use of house yards. Every community member owns a yard at their house. This activity is done in collaboration with housewives who are not working at Pelambuan Selatan sub-district, Banjarmasin, who have irregular monthly incomes. House yards are used effectively to cultivate vegetables and medicinal plants on organic media which are arranged vertically. Such use is expected to be able to help families meeting their daily nutritional needs or in case they need medicinal aids. This activity is also expected to be sustainable so that the yield can be sold for some extra household income. The methods applied in this program include (1) Dissemination on the Utilization of House Yards, Planting Techniques, and Information on Vegetable Crops and Medicinal Plants; (2) Provision of vegetables and medicinal plants seedlings and seeds, growing media, watering cans, and plant racks; (3) Mentoring to the partners on the process of seedling, planting, and maintenance.
\end{abstract}

Key Words: House Yards, Vegetables, Medicinal Plants.

\section{PENDAHULUAN}

Pekarangan bukan hanya untuk menciptakan keindahan dan kesejukan saja, namun jika menanam tanaman yang produktif seperti hortikultura (tanaman buah-buahan, sayur-sayuran dan tanaman hias), rempah-rempah, obat-obatan, bumbu-bumbuan dan lainnya akan memberikan keuntungan yang berlipat ganda.

Budidaya tanaman pangan dipekarangan dapat mengatasi gejolak harga dan dapat memenuhi kebutuhan pangan dan gizi keluarga serta dapat meningkatlan pendapatan yang akhirnya dapat meningkatkan kesejahteraan keluarga sehingga mampu mewujudkan kemandirian pangan di tingkat rumah tangga.

Tanaman Obat Keluarga (TOGA) dalah jenis tumbuhan yang merupakan hasil budidaya rumahan namun terbukti untuk menyembuhkan berbagai macam penyakit dan serangan radikal bebas lainnya. Meski hasil budidaya rumahan, Tumbuhan obat herbal atau lebih sering dikenal dengan apotik hidup ini mempunyai efek yang cukup baik untuk kesehatan tubuh manusia. Pemanfaatan tumbuhan sebagai obat 
lama dikenal untuk mengobati berbagai jenis penyakit ringan yang salah satunya adalah penyakit ringan seperti masuk angin dan flu. Namun dengan meningkatnya penelitian mengenai macam tanaman obat yang tersedia di lingkungan kita, Maka diketahui juga bahwa kemampuan dalam menyembuhkan, Tanaman obat juga tidak kalah dengan obat yang sudah banyak terjual di toko atau apotik.

Pemanfaatan tumbuhan obat pada umumnya adalah terdapat pada penggunaan sebagai bahan rempah atau bumbu masakan yang mempunyai fungsi sebagai penambah rasa dan juga aroma. Sehingga jika kita kutip disini, Tanaman obat bisa berupa daun, bumbu masakan, rimpang, biji, buah, bunga dan juga batan serta akar, selain itu dapat mengkonsumsinya sebagai obat, sehingga tidak bergantung pada Obat-obatan kimia yang mempuntai efek samping. Oleh karena itu, Tanaman Apotik hidup merupakan salah satu alternatif yang bisa digunakan untuk menjaga dan merawat kesehatan kita secara alami dengan tanpa adanya efek samping.

Mitra Pengabdian kepada masyarakat adalah ibu-ibu rumah tangga yang bertempat di Banjarmasin. Kondisi pekarangan masih memungkinkan untuk bertanam secara vertikal dengan menggunakan rak model tangga 2 susun untuk mengoptimalkan lahan sempit. Dengan lokasi yang memadai ini , sehingga Universitas Terbuka cocok untuk melakukan PkM (Pengabdian kepada Masyarakat) di lingkungan ini.

Tujuan dari kegiatan ini adalah mengoptimalkan pemanfaatan pekarangan rumah sebagai sumber pemenuhan gizi anggota keluarga dan apotik hidup, selain itu dapat menambah pendapatankeluarga baik melalui efisiensi penurunan biaya belanja keluarga meupun penjualan pelimpahan produk yang dihasilkan serta meningkatkan pengetahuan masyarakat dalam memanfaatkan pekarangan sempit dengan budidaya tanaman sayuran dan TOGA secara organik bebas pestisida.

\section{KAJIAN TEORI}

\section{- Pekarangan Rumah}

Pekarangan Rumah dapat dijadikan sumber pemenuhan gizi dan apotik hidup bagi anggota keluarga dengan teknik dan penataan yang benar dengan memanfaatkan disela-sela aktivitas rumah tanggauntukmerawat tanaman sayuran dan TOGA. Dengan memetik hasil tanaman apalagi dari pekarangan sendiri menjamin kita mendapatkan sayuran yang sehat dan higienis tanpa bahan kimia atau pestisida serta obat-obatan dari tanaman herbal sehingga tidak menimbulkan efek negatif.

Halaman sempit bukan alasan untuk tidak bisa berkebun, sebab pada prinsipnya budidaya tanaman itu bisa dilakukan di mana saja asalkan ada cahaya dan sirkulasi udara yang optimal. Tidak hanya di halaman sempit, di rumah yang tidak punya halaman sama sekali seperti di rumah susunpun hal itu bisa dilakukan ( Maharanto, 2005 ). 


\section{- Media Tanam}

Media tanam adalah bahan yang digunakan untuk tumbuh dan berkembangnya akar tanaman. Media tanam merupakan komponen utama dan sangat mempengaruhi keberhasilan penanaman sayuran organik. Tanah yang digunakan adalah tanah organik yang subur dan belum tercemar bahan-bahan kimia. Pupuk yang digunakan juga pupuk organik seperti pupuk kompos dan pupuk kandang.

Media tanam memiliki fungsi untuk menopang tanaman, memberikan nutrisi dan menyediakan tempat bagi akar tanaman untuk tumbuh dan berkembang. Lewat media tanam tumbuh-tumbuhan mendapatkan sebagian besar nutrisinya. Untuk budidaya tanaman dalam wadah pot atau polybag, media tanam dibuat sebagai pengganti tanah. Oleh karena itu, harus bisa menggantikann fungsi tanah bagi tanaman.

\section{- Jenis Sayuran Organik}

Menanam sayuran organik di pekarangan rumah sendiri dapat menjamin kesehatan seluruh anggota keluarga. Beberapa sayuran organik yang mudah ditanam pada polybag adalah :

\section{- $\quad$ Cabai (Capsicum sp.)}

Cabai merupakan salah satu komoditas sayuran yang sangat populer karena dalam masakan Indonesia, cabai digunakan sebagai penyedap rasa. Tanaman cabai bisa ditanam diberbagai ketinggian, mulai dataran rendah hinga dataran tinggi, tergantung jenis atau varietasnya.

\section{- Tomat (Solanum lycopersicum)}

Tomat merupakan salah satu jenis sayuran yang digemari oleh masyarakat. Cita rasa yang khas dapat menambah kelezatan berbagai makanan. tanaman tomat cocok ditanam di dataran rendah sampai dataran tinggi tergantung pada varietasnya. Tanaman tomat sangat menarik jika ditanam di pot atau polibag karena termasuk tanaman yang rajin berbuah.

\section{- $\quad$ Terung (Solanum melongena)}

Terung termasuk tanaman tahun yang berumur sekitar 3-4 bulan. Tanaman terung dapat tumbuh dan beradaptasi dengan baik pada daerah tropis. Sebelum ditanam, sebaiknya benih terung disemai terlebih dulu agar pertumbuhannya maksimal.

\section{- Caisim (Brassica campestris L-Spp)}

Caisin adalah sayuran yang memiliki ciri batang panjang yang tegap, daun berwarna hijau yang lebar, pipih, halus, tidak berbulu, dan tidak berkrop. Caisin membutuhkan tanah yang subur, gembur, dan kaya bahan organik.

\section{- Pakcoy (Brassica chinensis)}

Pakcoy adalah sayuran yang masih sekeluarga dengan Brassicaceae. Sayuran pakcoy ini masih satu golongan dengan sawi dan sering sekali disebut dengan berbagai nama, seperti dawi sendok, sawi manis, atau sawi daging karena memiliki pangkal sayur yang tebal dan lembut seperti halnya daging. Sayuran ini biasanya digunakan dalam bahan sup atau penghias makanan. 


\section{- Bayam (Amaranthus sp)}

Tanaman bayam sangat mudah tumbuh dan cocok bagi mereka yang baru belajar menanam. Jenis varietas bayam yang sering ditanam petani, yaitu Amaranthus bicolor dan A.dubius.

\section{- Kangkung (lpomea sp.)}

Tanaman kangkung mudah tumbuh. Kangkung cocok ditanam disemua tempat, mulai dataran tinggi hingga dataran rendah. Ada dua tipe kangkung yang biasa dibudidayakan, yaitu kangkung darat dan kangkung air. Kangkung darat memiliki ciri, diantaranya daun sempit, bunga putih dan batang berwarna hijau. Adapun kangkung air mempunyai ciri berupa daun lebar, berbentuk mata anak panah, bunga berwarna merah jambu, dan batang berwarna putih.

Jenis Tanaman Obat Keluarga (TOGA)

\section{- Lidah Buaya}

Lidah Buaya (Aloe Vera) adalah bahan alami yang banyak memiliki manfaat bagi kesehatan dan kecantikan, termasuk membantu menjaga kulit tetap sehat serta memperbaiki karena memiliki sifat penyembuhan. Bahkan Aloe vera bisa digunakan oleh semua orang dengan jenis kulit yang berbedabeda. Tanaman ini bisa dimanfaatkan sebagai gel, minyak, jus, krim, sabun, dan suplemen kesehatan.

\section{- Kumis Kucing}

Senyawa kimia yang terkandung dalam kumis kucing bisa membantu mengurangi tekanan darah. Kumis kucing dipercaya secara efektif dapat mengikis batu ginjal, infeksi kandung kemih, infeksi salurah kemih, sering buang air kecil, dan batu kandung kemih. Maafaat ini sudah terbukti dalam beberapa studi Klinis.

\section{- Kemangi}

Daun kemangi segar mengandung vitamin A yang berperan utama dalam tubuh untuk mendukung pematangan sel. Hal ini juga mengatur aktivitas gen, menghidupkan gen sel-sel baru yang berkontribusi untuk fungsi jaringan. Kemangi juga mengandung vitamin $\mathrm{K}$ yang berguna untuk tubuh untuk mengaktifkan protein yang diperlukan untuk pertumbuhan jaringan yang sehat, termasuk tulang rawan, jaringan perut dan jaringan paru-paru. Vitamin $\mathrm{K}$ juga berperan membatu pembekuan darah untuk mencegah memar, perdarahan, dan kehilangan banyak darah.

\section{- Serai}

Serai termasuk sumber yang baik vitamin A dan C, asam folat, magnesium, seng, tembaga, zat besi, kalium, fosfor, kalsium dan mangan. Manfaatnya antara lain membantu menjaga kesehatan pencernaan, mengendalikan kadar kolesterol, membersihkan dan mendetoksifikasi hati, menyembuhkan pilek dan flu, membantu melawan kanker, mengurangi nyeri sendi, membantu meningkatkan produksi ASI, menyingkirkan depresi, mengurangi bau badan, dan menjaga kulit tetap sehat.

\section{- Kunyit}

Manfaat kunyit banyak digunakan sebagai ramuan jamu karena berkhasiat menyejukkan, membersihkan, mengeringkan, menghilangkan gatal, dan menyembuhkan kesemutan. Bermanfaat juga sebagai anti inflamasi, anti oksidan, anti mikroba, pencegah kanker, anti tumor, dan menurunkan kadar lemak darah dan kolesterol, serta sebagai pembersih darah. 
- $\underline{\text { Jahe }}$

Mengandung senyawa oleoresin yang lebih dikenal sebagai gingerol yang bersifat sebagai antioksidan, sebagai komponen bioaktif anti penuaan. Bermanfaat melindungi lemak/ membran dari oksidasi, menghambat oksidasi kolesterol, dan meningkatkan kekebalan tubuh, masuk angin, sakit kepala, sakit kepala sebelah, mabuk kendaraan dan param untuk anggota badan yang terkilir.

\section{- $\quad \underline{\text { Seledri }}$}

Seledri adalah sumber yang sangat kaya akan antioksidan dan vitamin $\mathrm{K}$, asam folat, vitamin $\mathrm{A}$, kalium, dan vitamin $\mathrm{C}$. seledri selalu dikaitkan dengan menurunkan tekanan darah, dan studi terbaru menunjukkan bahwa seledri juga efektif mencegah kanker, menyeimbangkan asam basa, menurunkan kolesterol, mengatasi dan mencegah sembelit, menenangkan peradangan, membersihkan ginjal dari racun, menenangkan pada system saraf, membuang kelebihan air dalam tubuh melalui urine, meningkatkan sekresi ASI, mengoptimalkan metabolism, meningkatkan massa tulang, dan membantu mengatur detak jantung.

\section{- $\quad$ Penanaman}

Benih berupa biji ditanamkan ke media tanam dengan kedalaman antara 3-5 cm. Khusus untuk tanaman berbuah seperti tomat dan terong, sebelum ditanam sebaiknya disemai terlebih dahulu agar pertumbuhannya lebih optimal. Sedangkan sayuran berdaun dan sayuran rambat tidak perlu melewati proses penyemaian ini (Zaenal Abidin, 2015)

\section{- Pemeliharaan}

Bentuk perawatan sayuran organikberupa penyiraman secara teratur dan pemupukan ulang. Tanaman budidaya idealnya harus disiram setiap dua kali sehari saat pagi dan sore. Sedangkan, pemupukan ulang bisa disesuaikan dengan jenis sayuran-sayuran yang dipelihara tersebut. Berikan pupuk majemuk yang mengandung fosfor untuk sayuran berbuah dan berikan pupuk urea untuk sayuran berdaun (Zaenal Abidin, 2015)

Pengendalian hama penyakit lebih mudah dilakukan dalam kegiatan pemanfaatan pekarangan dengan tanaman sayur ini. Untuk tanaman di pot kemungkinan penularan penyakit melalui akar jarang terjadi karena akar diabatasi oleh pot. Pada lahan pekarangan yang sempit kita bisa mengendalikan hama dan penyakit secara manual sehingga penggunaan bahan kimia dapat dibatasi. Hal ini akan membuat sayuran yang dihasilkan dari pekarangan lebih sehat untuk dikonsumsi, karena merupakan sayuran organik (Prapanca, 2005).

\section{- Pemanenan}

Sayuran organik biasanya dapat dipanen setelah berusia sebulan. Pemanenan dilakukan dengan memetik bagian tanaman yang bisa dikonsumsi, seperti buah, daun, batang, atau bunga. Dalam budidaya skala kecil di lahan sempit, setiap tanaman bisa dipanen sebanyak dua kali. Selanjutnya, media tanam dapat didaur ulang kembali untuk digunakan menanam sayuran-sayuran yang lainnya (Zaenal Abidin, 2015) 


\section{METODE PELAKSANAAN}

Dalam memperoleh hasil yang baik, kegiatan pengabdian masyakarat ini perlu perencanaan yang baik dan matang. Kegiatan ini diawali dengan melakukan penyuluhan, penerapan langsung ke mitra PkM, pendampingan, evaluasi kegiatan, dan monitoring dari tim pelaksana abdimas dan LPPM.

Metode yang akan dilaksanakan adalah :

\begin{tabular}{|c|l|}
\hline No & \multicolumn{1}{|c|}{ Uraian Kegiatan } \\
\hline 1. & Penyuluhan \\
\hline 2. & $\begin{array}{l}\text { Penyaluran bantuan benih dan bibit sayuran, bibit tanaman obat, polybag, gembor, } \\
\text { tanah pupuk, obat semut dan rak susun }\end{array}$ \\
\hline 3. & Pendampingan dalam penanaman benih dan bibit, \\
\hline 4. & Pelaporan \\
\hline 5. & Monitoring \\
\hline
\end{tabular}

\section{HASIL DAN PEMBAHASAN}

Kegiatan diawali dengan melakukan survey pada lokasi yang dianggap dapat menerima bantuan, kemudian dilakukan need assessment di lokasi tersebut untuk mendapatkan sasaran kegiatan yang dapat dilakukan untuk membantu masyarakat setempat. Untuk pelaksanaan ini terdapat 25 peserta atau mitra PkM (Ibu-ibu rumah tangga) yang ikut berpartisipasi. Kegiatan PkM dapat diuraikan sebagai berikut: 1. Memberikan penyuluhan tentang (1) Pemanfaatan Pekarangan Rumah (2) Teknik Bertanam , (3) Mengenal Tanaman Sayuran dan TOGA.

Dalam pelaksanaan ini, mitra sangat antusias untuk mengikuti program ini untuk kemudahan mendapatkan sayuran higienis di halaman atau pekarangan rumah. Pada pelaksanaan ini pun, bukan hanya mitra penerima bantuan saja, ketua RT dan bapak-bapak warga masyarakat ikut berpartisipasi.

2. Penyaluran bantuan benih/bibit tanaman sayuran dan TOGA yang mudah penanaman dan perawatannya beserta media tanam. Dengan kegiatan ini, diharapkan mitra memperoleh sayuran yang higienis dan bebas pestisida.

3. Pendampingan kepada mitra dalam penerapan langsung pada pekarangan rumah masing-masing mitra.

4. Monitoring pelaksanaan kegiatan PkM (evaluasi kegiatan)

Terdapat 25 peserta PkM dan perwakilan ketua RT yang hadir pada penyamaan persepsi yang hadir pada penyuluhan. Terlihat antusias mereka untuk belajar bercocoktanam di pekarangan rumahnya.

Untuk memastikan peserta PkM melakukan penyemaian, penanaman, dan pemeliharaan atau perawatan oleh Tim Pengabdian kepada Masyarakat UPBJJ-UT Banjarmasin dilakukan pendampingan dan monitoring. Begitupun oleh LPPM-UT, telah melakukan pemantauan ke lokasi PkM.

\section{SIMPULAN}

Mitra Kegiatan Pengabdian kepada Masyarakat sangat antusias mengikuti program PkM ini, terlihat dengan keikutsertaan mereka mengikuti penyuluhan mengenai pemanfaatan pekarangan rumah, teknik bertanam, dan mengenal tanaman sayuran dan TOGA serta kegiatan langsung mempraktekkan penyemaian, penanaman dan penyiangan. Hal ini terlihat saat dilakukan pendampingan dan monitoring oleh tim dan LPPM. 


\section{REFERENSI}

Badan Ketahanan Pangan Daerah Provinsi Jawa Barat, 2015.Kontribusi Sayuran dalam Pola Pangan Harapan Keluarga Indonesia,http://bkpd.jabarprov.go.id/kontribusi-sayuran-dalam-pola-panganharapan-keluarga-indonesial, diakses tanggal 2 Maret 2016.

BPTP Sulawesi Selatan, 2012. Budidaya Sayuran di Lahan Pekarangan. http://sulsel.litbang.pertanian.go.id/ind/index.php?option=com_content\&view=article\&id=802:budidaya-sayuran-di-lahan-pekarangan-tahun-terbit-2012, diakses tanggal 2 Maret 2016.

Maharanto, 2005. Sayuran Pot di Negara 4 Musim. Trubus Edisi September No.286. Tahun XXIV.2000. hal 4-6.

Paeru, R.H dan Trias Qurnia Dewi, 2015. Panduan Praktis Bertanam Sayuran di Pekarangan. Penebar Swadaya. Jakarta

Tim Agro Media Pusstaka, 2006. Memanfaatkan rumah dan pekarangan( Menanam sayur di pekarangan rumah). Agro Media Pustaka. Jakarta. 112 hal.

Zaenal Abidin, 2015. Tips Bercocok Tanam Sayuran Organik di Lahan Sempit. http://pakarbudidaya.blogspot.co.id/2015/05/tips-bercocok-tanam-sayuran-organik-di.html, diakses tanggal 2 Maret 2016. 